\title{
Input Calibration and Validation of RELAP5 Against CIRCUS-IV Single Channel Tests on Natural Circulation Two-Phase Flow Instability
}

\author{
Viet-Anh Phung, ${ }^{1}$ Pavel Kudinov, ${ }^{1}$ Dmitry Grishchenko, ${ }^{1}$ and Martin Rohde ${ }^{2}$ \\ ${ }^{1}$ Nuclear Power Safety Division, KTH Royal Institute of Technology, 10691 Stockholm, Sweden \\ ${ }^{2}$ Department of Radiation Science and Technology, Delft University of Technology, 2629 JB, Delft, Netherlands
}

Correspondence should be addressed to Viet-Anh Phung; vaphung@kth.se

Received 11 May 2015; Accepted 9 August 2015

Academic Editor: Eugenijus Ušpuras

Copyright ( $\odot 2015$ Viet-Anh Phung et al. This is an open access article distributed under the Creative Commons Attribution License, which permits unrestricted use, distribution, and reproduction in any medium, provided the original work is properly cited.

\begin{abstract}
RELAP5 is a system thermal-hydraulic code that is used to perform safety analysis on nuclear reactors. Since the code is based on steady state, two-phase flow regime maps, there is a concern that RELAP5 may provide significant errors for rapid transient conditions. In this work, the capability of RELAP5 code to predict the oscillatory behavior of a natural circulation driven, twophase flow at low pressure is investigated. The simulations are compared with a series of experiments that were performed in the CIRCUS-IV facility at the Delft University of Technology. For this purpose, we developed a procedure for calibration of the input and code validation. The procedure employs (i) multiple parameters measured in different regimes, (ii) independent consideration of the subsections of the loop, and (iii) assessment of importance of the uncertain input parameters. We found that predicted system parameters are less sensitive to variations of the uncertain input and boundary conditions in high frequency oscillations regime. It is shown that calculation results overlap experimental values, except for the high frequency oscillations regime where the maximum inlet flow rate was overestimated. This finding agrees with the idea that steady state, two-phase flow regime maps might be one of the possible reasons for the discrepancy in case of rapid transients in two-phase systems.
\end{abstract}

\section{Introduction}

RELAP5 code [1] has been widely used in nuclear reactor safety analysis. The code uses two-phase flow regime maps with criteria for transition between different regimes based on results of fully developed, steady state experiments. The flow regime changes based on the instantaneous flow parameters with no regard to the flow history (e.g., acceleration or deceleration of the flow). In reality, flow regime transitions need time to develop [2]. Transient flow regimes can be different from those steady state ones at the same instantaneous flow parameters [3]. Rates of exchange of mass, energy, and momentum between the vapor and liquid phases depend on the flow regime. As a consequence, there is a concern that the steady state flow regime maps in RELAP5 may lead to significant errors for transients with rapidly changing flow regimes. Such transients can be found during two-phase flow natural circulation instabilities, being an important safety issue for boiling water reactors (BWRs) [4].
The thermal hydraulics of two-phase flow instability has been investigated extensively both experimentally and analytically for decades. Sophisticated test facilities have been used. Wissler et al. [5] performed early studies of two-phase oscillatory flow in natural circulation loop. Boure et al. [6] classified different types of instability. Aritomi et al. [7] and Chiang et al. [8] studied instability in natural circulation BWR (NCBWR) startup conditions at low power and atmospheric pressure. Furuya et al. $[9,10]$ investigated mechanism of flashing induced instability in SIRIUS-N facility. Stability maps of NCBWR at various pressures and effect of geometric parameters were studied by de Kruijf et al. [11, 12] and Zboray et al. [13]. With the large scale PUMA test facility, Ishii et al. [14] and Kuran et al. [15] have investigated two-phase flow instability and other thermal-hydraulic phenomena in NCBWR. At the CIRCUS facility, Manera and van der Hagen [16] carried out studies on the instability during NCBWR startup. Later at the same facility, Marcel et al. [17] performed study on parallel channels flashing instability. Rohde et al. 
[18] analyzed stability performance of a NCBWR system with the GENESIS facility which uses R134a as working fluid and has an artificial void reactivity feedback system. These experimental studies have provided insight and data for modeling, code validation, and the development of empirical correlations.

Analytical studies resulted in the development of models for two-phase flow instability that could be implemented in system codes $[19,20]$. Two-phase flow instability was investigated using system codes by Kolev [21], Shiralkar et al. [22], and Rohde et al. [18]. The amplitude and frequency of flashing induced instability at the CIRCUS facility were studied by Schäfer and Manera [23] using ATHLET code. Kozmenkov et al. [24] simulated the flashing induced instability at the CIRCUS using RELAP5, thereby mostly comparing flow rates and pressures.

Although an extensive number of experimental investigations have been carried out, only few of those were exclusively designed for code validation. Also uncertainties in modeling have not been addressed explicitly in the previous analytical works. Assessment of the uncertainties and their influence on behavior of the system is an essential element of the code validation [25]. One of the sources of uncertainties is code input parameters that are not measured directly in the experiment. In order to reduce this uncertainty, it is important to consider need for code input calibration in the design of the experiments. Specifically, sufficient number of constraints should be provided in the experimental data in order to enable inference of the input parameters such as heat and pressure losses. Another difficulty in code validation against physically unstable system is related to the fact that small variations in uncertain input parameters may lead to big variations in the system response both in the experiment and in the simulation $[26,27]$.

The goal of the present study is to validate the predictive capabilities of RELAP5 against two-phase natural circulation flow instability experiments. For this purpose, we (i) developed experimental procedures and carried out a set of tests in CIRCUS-IV facility with single test channel and constant system pressure and (ii) developed and applied a procedure for the calibration of the uncertain parameters in the code input and for validation of the code. The procedure reduces uncertainty in the code input using multiple measured parameters in different test regimes for the calibration.

First, we provide a description of the test facility, experiments, and the RELAP5 input model (Sections 2 and 3). Second, we describe the procedure for input calibration and code validation (Section 4). Finally, the results of the calibration and validation are discussed (Section 5).

\section{CIRCUS-IV Single Channel Experiments}

The CIRCUS-IV [17] is a natural circulation test loop facility, which was designed to investigate two-phase flow instability in NCBWRs during the startup phase.

The CIRCUS-IV thermal-hydraulic loop (Figure 1) consists of a test section with four parallel channels, a heat exchanger, a downcomer, two upper buffer vessels with steam domes, and a lower buffer vessel with a preheater. Each

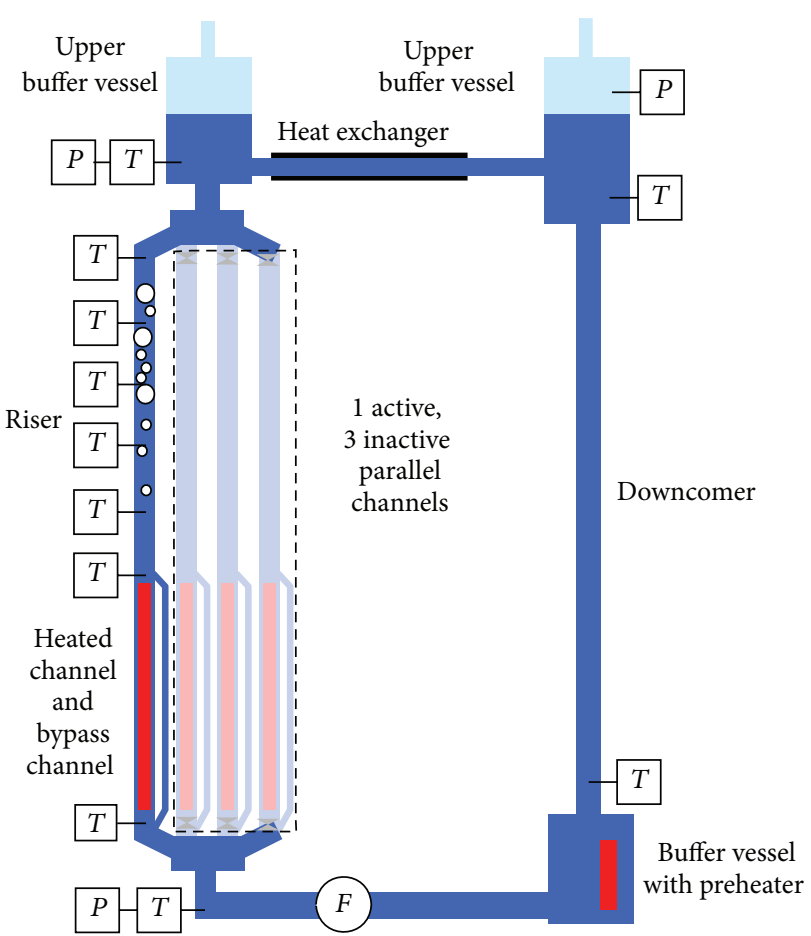

FIGURE 1: Scheme of the CIRCUS-IV test facility in the single channel tests.

parallel channel consists of a heated section $(1.95 \mathrm{~m})$ with a heater rod inside, a bypass channel, and a riser section $(3 \mathrm{~m})$. The temperature of the water at the inlet of the test section is controlled by the preheater.

The main measurement system of the facility consists of the following instruments (Figure 1):

(1) Volumetric magnetic flow-meter at the inlet of the test section.

(2) Thermocouples in the test section and in the buffer vessels.

(3) Pressure sensors at the inlet of the test section, the riser outlet, and the steam dome.

Measurement uncertainties were $\pm 1^{\circ} \mathrm{C}$ for temperature, $\pm 30 \mathrm{mbar}$ for pressure, and $\pm 0.0002 \mathrm{l} / \mathrm{s}$ for flow rate measurements.

For the code validation purpose, in order to eliminate possible effects of parallel channels, the experiments were performed with a single opened channel in the test section. The steam domes were opened to the atmosphere to maintain constant pressure, since dynamics of the flow instability is sensitive to the variations of the steam dome pressure [28]. The bypass channels were not used in the experiments reported here.

A set of three experiments were performed at inlet water temperatures $89^{\circ} \mathrm{C}, 93^{\circ} \mathrm{C}$, and $100^{\circ} \mathrm{C}$. System pressure and heating power were maintained at 1 bar and $2.5 \mathrm{~kW}$, respectively. The test matrix is given in Table 1 . In test S-1 at low inlet water temperature, the flow remains in singlephase steady state natural circulation. In test I-1, intermittent 
TABLE 1: Test conditions and regimes.

\begin{tabular}{lcccc}
\hline Test number & $\begin{array}{c}\text { Pressure } \\
(\text { bar })\end{array}$ & $\begin{array}{c}\text { Power } \\
(\mathrm{kW})\end{array}$ & $\begin{array}{c}\text { Inlet temp. } \\
\left({ }^{\circ} \mathrm{C}\right)\end{array}$ & Test regime \\
\hline S-1 & 1 & 2.5 & 89.0 & $\begin{array}{c}\text { Single-phase } \\
\text { steady state } \\
\text { I-1 }\end{array}$ \\
I-2 & 1 & 2.5 & 92.8 & $\begin{array}{l}\text { Two-phase } \\
\text { instability } \\
\text { Two-phase } \\
\text { instability }\end{array}$ \\
\hline
\end{tabular}

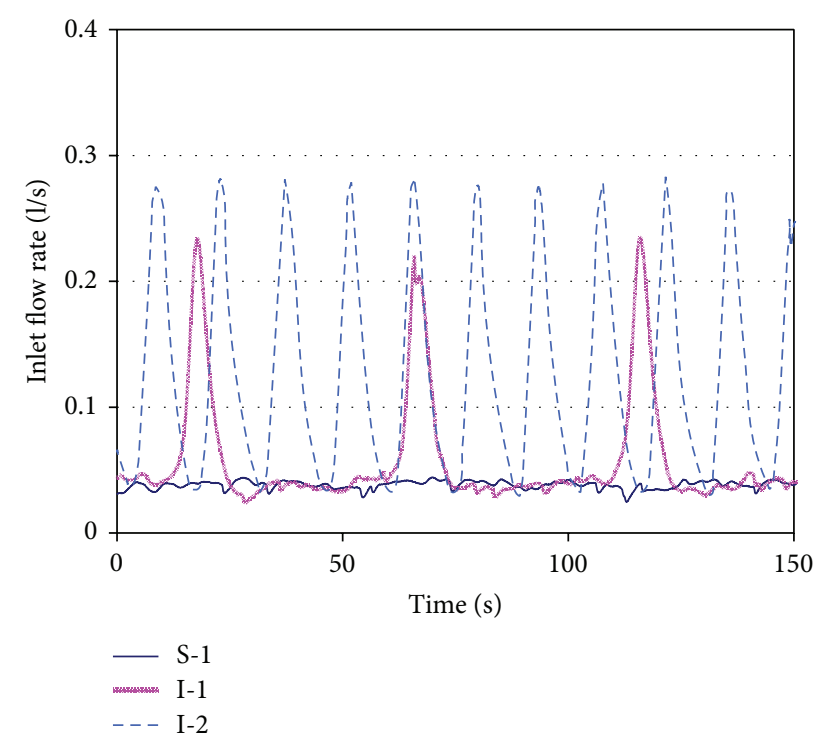

FIGURE 2: Inlet flow rate in the CIRCUS-IV single channel experiments.

boiling develops in the riser which creates two-phase flow with low frequency oscillation. In test I-2, further increase in the inlet water temperature leads to higher frequency and higher amplitude of two-phase flow oscillations.

Figure 2 shows the inlet flow rate in the CIRCUS-IV single channel experiments. A flashing instability period consists of two phases: a flashing/boiling period and an incubation period. During the flashing period, the system experiences a strong peak in the inlet flow rate (Figure 2), a reverse peak in the inlet pressure, and a strong decrease in the riser water temperature. The flashing period contains the maximum value of inlet flow rate, the minimum value of inlet pressure, and the maximum value of water temperature in the riser. During the incubation period, the flow in the system remains at subcooled conditions (Figure 2) reaching the minimum value of inlet flow rate, the maximum value of inlet pressure, and the minimum value of riser water temperature.

\section{RELAP5 Model of The Facility}

RELAP5/MOD 3.3GL [29] was used in this work. Figure 3 shows the nodalization of the CIRCUS-IV single channel model. The model includes the heated channel with the heater

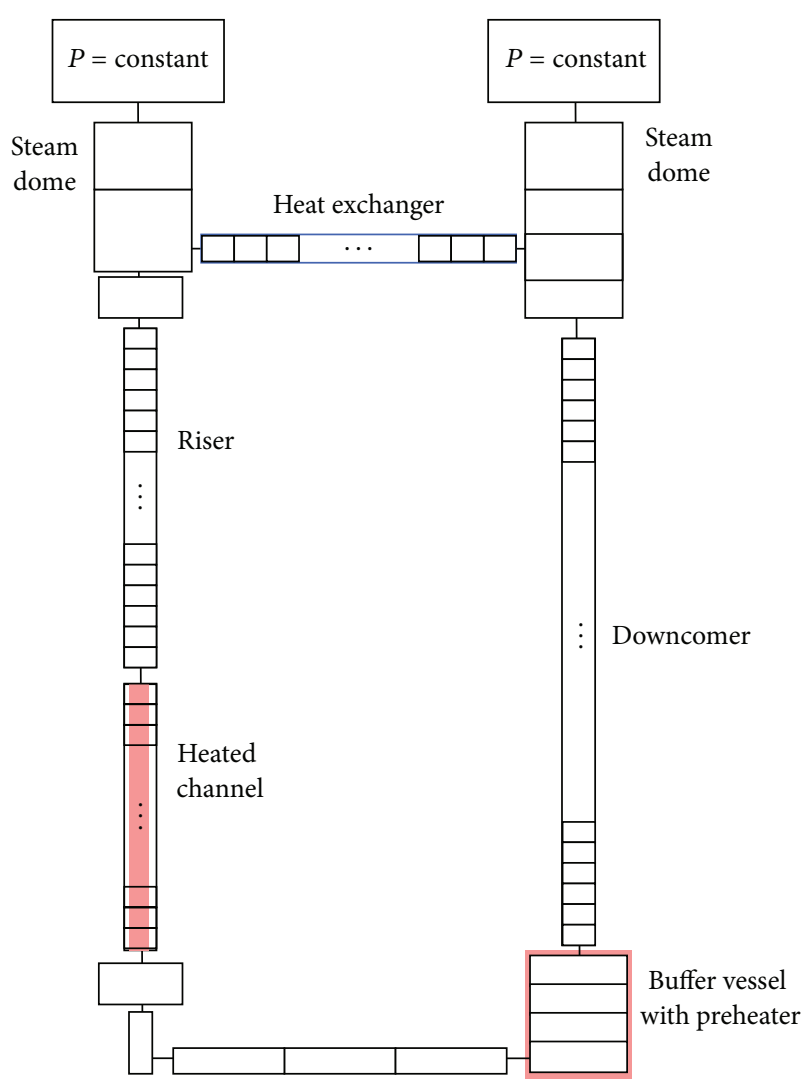

FIgURE 3: Nodalization of the CIRCUS-IV single channel model in RELAP5.

rod, the riser, the heat exchanger, the downcomer, two upper buffer vessels with steam domes, and the lower buffer vessel with the preheater. Since thermal inertia in the components of the system has a significant effect on characteristic of the instability [30], the wall heat structures for the heated channel, the riser, the heat exchanger, and the downcomer were incorporated.

The following computed thermal-hydraulic parameters were compared with the measurement data: inlet flow rate, inlet water temperature, riser water temperature, inlet pressure, and oscillation period.

\section{Input Calibration and Code Validation Procedure}

It is important to separate data which are used for input calibration and for code validation; otherwise results of the validation are not generally reliable. Therefore, single-phase steady state test data were used for code input calibration. Data from natural circulation two-phase instability tests were then used for code validation.

The diagram in Figure 4 describes the procedure.

4.1. Stage 1: Code Input Calibration against Single-Phase Steady State. The first step consists of calibrating uncertain input parameters for the test section, which consists of the heated 


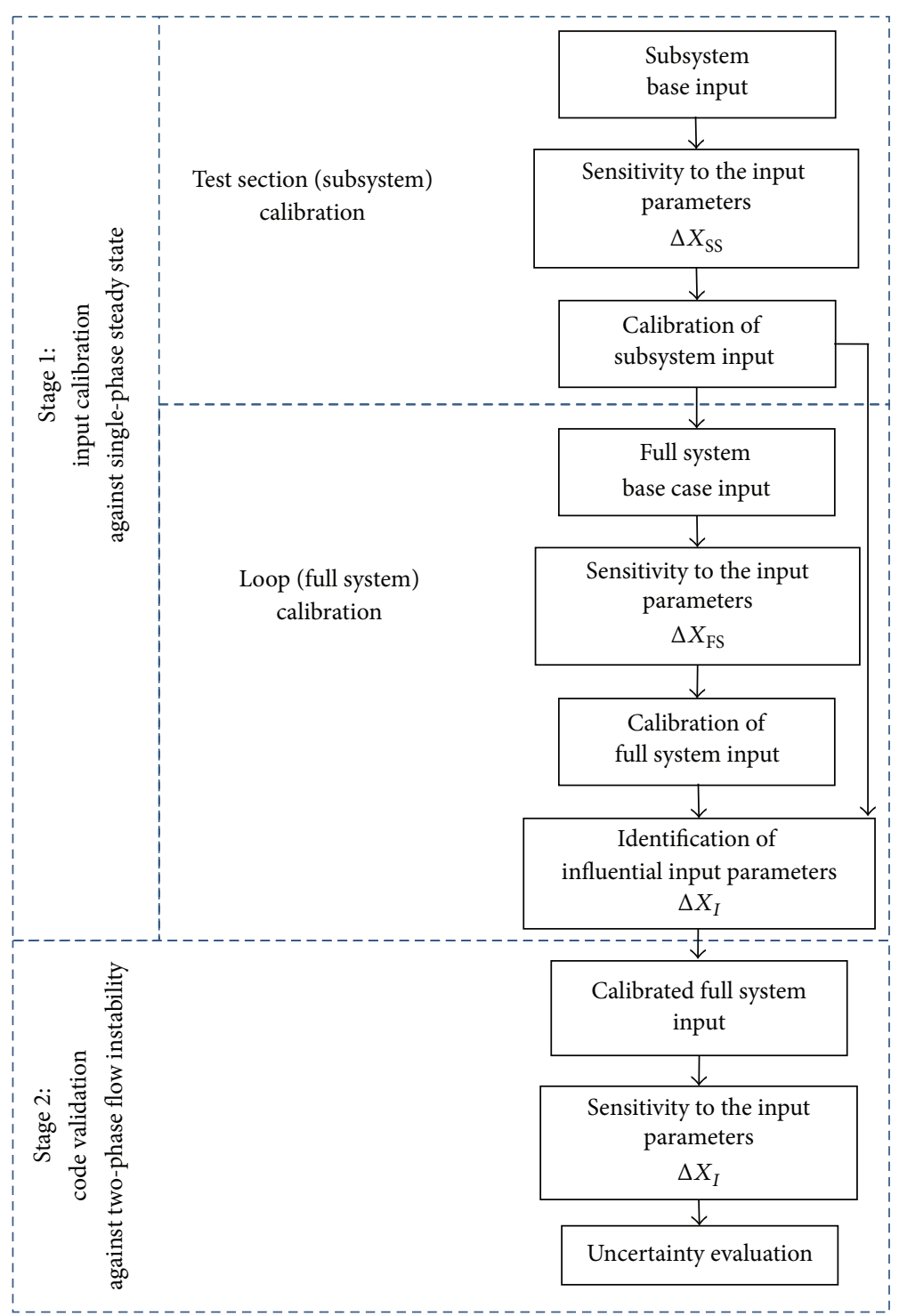

FIGURE 4: The procedure for input calibration and code validation with uncertainty assessment.

channel, the riser, and the steam dome (Figure 5). The data obtained from the test with single-phase steady state flow was used to set boundary conditions for the test section. In the second step, data of the entire loop in single-phase steady state test were used to calibrate the input. This two-step analysis reduces the number of uncertain input parameters in each step of the process.

Calibration of the input for the test section and then for the full loop follows the same procedure:

(1) The initial input for the calibration is built based on the available experimental data, first for the test section and then for the full loop. The full loop base case input includes data from the calibrated test section input.

(2) Sensitivity calculations are performed in order to understand the system response to the changes in the input parameters (denoted as $\Delta X_{\mathrm{SS}}$ for the test section and $\Delta X_{\mathrm{FS}}$ for the full loop in Figure 4).
(3) The calibration is carried out, considering importance of each uncertain input parameter and physically meaningful combination of their values. We considered dependencies between different uncertain input parameters and flow parameters (e.g., temperature, void fraction, and pressure). The ranges of the uncertain input parameters (e.g., riser heat loss) were estimated.

(4) After the full loop calibration, the most influential input parameters were identified for the code validation.

\subsection{Stage 2: Code Validation against Two-Phase Natural} Circulation Flow Instability. Consider the following:

(1) Two-phase flow instability cases were calculated using full loop inputs calibrated with the steady state data.

(2) Sensitivity calculations were carried out using most influential uncertain input parameters $\left(\Delta X_{I}\right)$. 


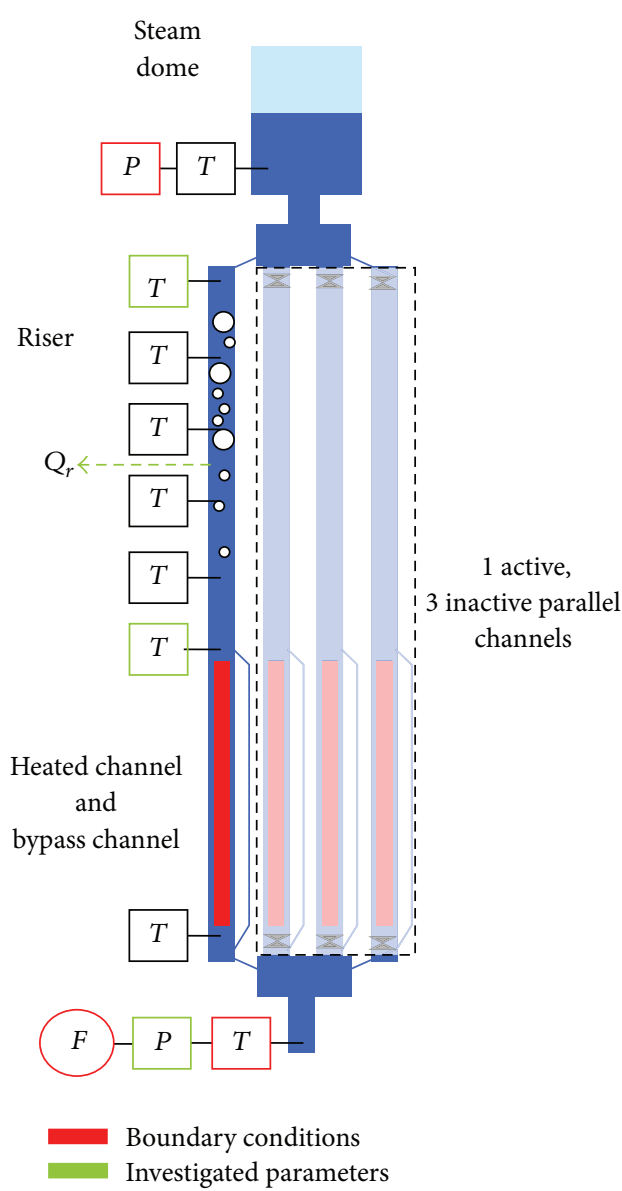

(a)

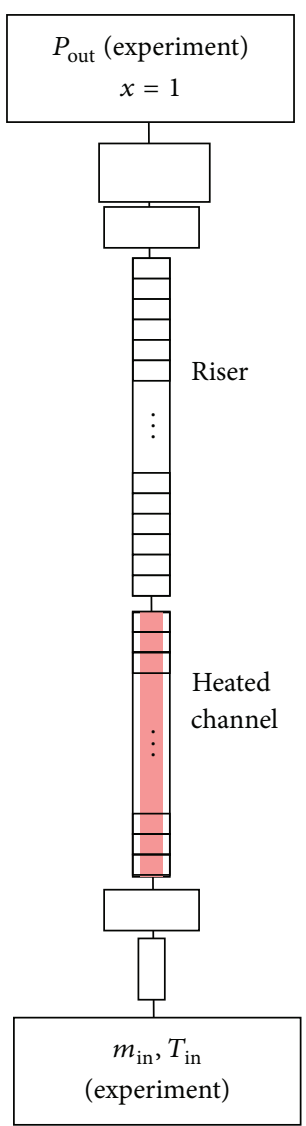

(b)

FIGURE 5: CIRCUS-IV single channel test section: (a) scheme and (b) RELAP5 nodalization.

(3) The ranges of the code prediction uncertainty were estimated based on the results of sensitivity calculations.

\section{Results and Discussion}

5.1. Stage 1: Input Calibration against Single-Phase Steady State. The single-phase steady state test S-1 was used in this stage.

Experimental sources of uncertainty which can affect simulation results include what follows:

(1) Temperature at the inlet of the test section, the outlet of the test section, and the downcomer.

(2) Pressure at the inlet of the test section.

(3) Loss coefficient or pressure drop at the inlet valve.

(4) Power of the heater in the test section.

(5) Heat losses along the riser to the environment.

(6) Heat losses along the downcomer to the environment.

(7) Loss coefficients in the loop elements with complex geometry.
A schematic of the test section and its nodalization in RELAP5 are shown in Figure 5. The boundary conditions of the test section are defined by the inlet water temperature, inlet mass flow rate, and outlet pressure (static quality $x=1$ ).

5.1.1. Test Section Input Calibration. The goal of this step is to calibrate uncertain parameters in the code input, namely, inlet temperature, heat loss in the riser, heater power, and inlet pressure loss coefficient. Uncertainty in prediction of single-phase steady state flow by RELAP5 is assumed to be small. Therefore, we can attribute the discrepancies between calculation and experiment to the uncertainty in the boundary conditions or uncertainties in the measurements of thermal hydraulic parameters. First, a calculation was carried out using a base case input that used experimental values of the heater power, flow rate, and temperatures at inlet and outlet of the test section. Heat losses in the riser were not taken into account at this step. Second, we varied uncertain input parameters (Table 2) to assess variation of system response parameters. The inlet flow rate was not varied due to the expected small measurement uncertainty. Finally, the test section input was calibrated to reduce the discrepancy between prediction and experiment. 
TABLE 2: Varied uncertain input parameters in the parametric study for the test section.

\begin{tabular}{lcc}
\hline Input parameter & Base input & Varied values \\
\hline Inlet temperature $\left({ }^{\circ} \mathrm{C}\right)$ & 89.0 & $88.0 ; 90.0$ \\
Riser heat loss $(\mathrm{kW})$ & 0 & $0.3 ; 0.5$ \\
Power $(\%)$ & 100 & $95 ; 105$ \\
$\begin{array}{l}\text { Inlet loss coefficient } \\
\begin{array}{l}\text { Additional outlet static pressure } \\
\text { (mbar) }\end{array}\end{array}$ & 0 & $100 ; 200$ \\
\hline
\end{tabular}

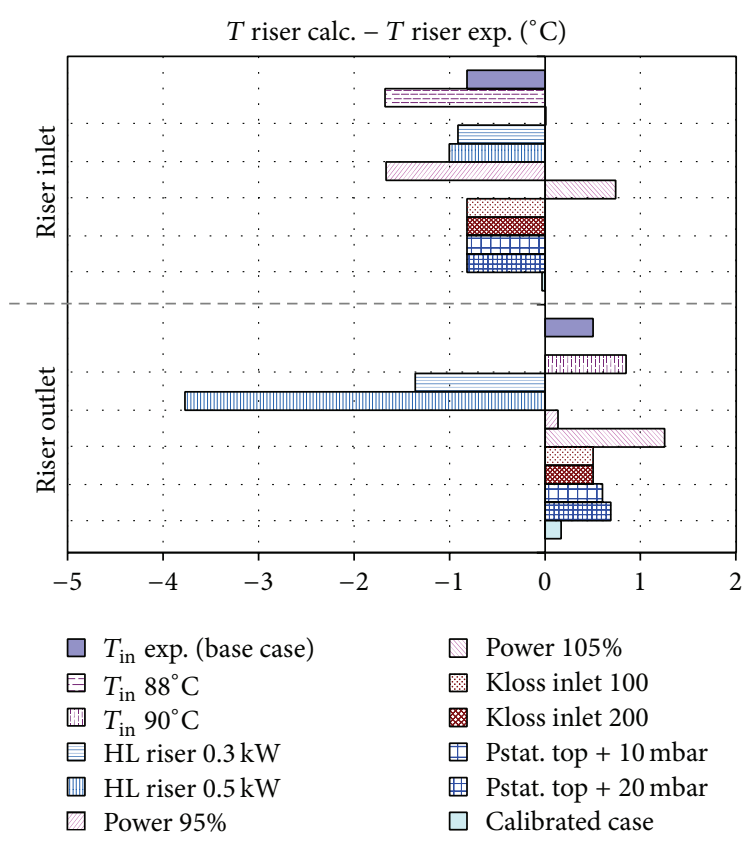

FIGURE 6: Difference between calculated and experimental temperature in the riser. Steady state test S-1.

Predicted riser inlet and outlet water temperatures were, respectively, $0.8^{\circ} \mathrm{C}$ lower and $0.5^{\circ} \mathrm{C}$ higher than the experimental values (Figure 6). Inlet pressure was underestimated by $15 \mathrm{mbar}$ (Figure 7). The discrepancies between predicted and measured values were larger than acceptable errors for steady state flow qualification: $0.1 \%$ for absolute pressure error and $0.5 \%$ for water temperature error [31].

In steady state flow we expected the following response of the system to variation of the uncertain input parameters:

(1) Increase in the inlet water temperature will lead to

(i) higher water temperature in the entire test section,

(ii) possible appearance of void in the riser,

(iii) smaller inlet pressure.

(2) Increase in the heat losses in the riser

(i) lowers the riser water temperature,

(ii) reduces void fraction (if any) in the riser,

(iii) increases the inlet pressure,

(iv) does not affect the inlet riser water temperature.

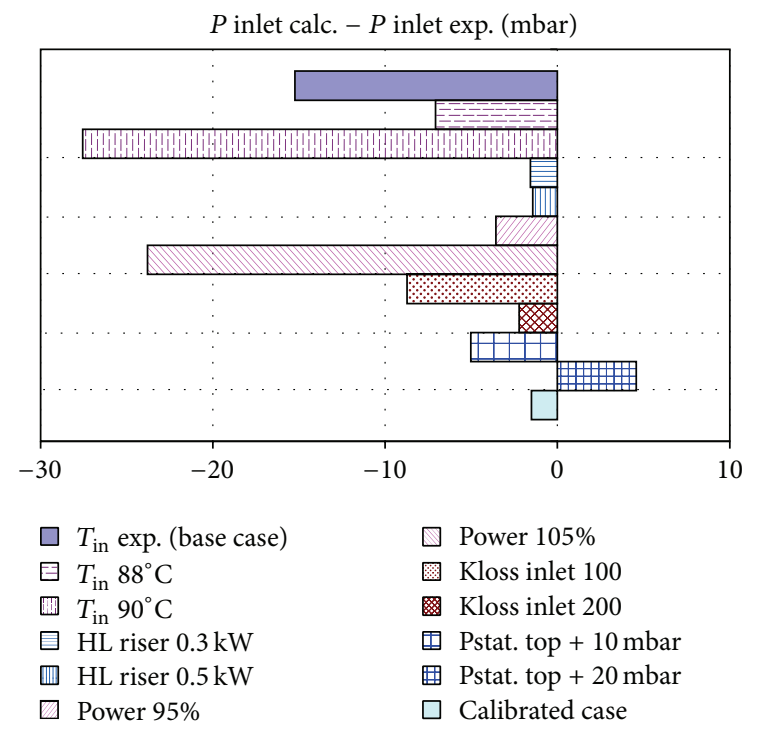

FIGURE 7: Difference between calculated and experimental pressure at the inlet. Steady state test S-1.

(3) Increase in the heater power affects the system in the same way as increasing the inlet water temperature.

(4) Increase in inlet loss coefficient only raises the inlet pressure and does not affect other parameters.

(5) Increase in the outlet pressure suppresses void (if any) in the test section and thus raises the inlet pressure.

Results presented in Figures 6 and 7 (and summarized in Table 3) confirm expected system behavior.

It is clear that in the base case input no single uncertain input parameter can be varied in order to match the experimental data by simultaneously

(i) reducing riser inlet temperature,

(ii) increasing riser outlet temperature,

(iii) reducing inlet pressure.

We found that generation of void was responsible for the underestimated inlet pressure. Underestimation of the riser inlet temperature can be explained by the offset in the measurement of the test section inlet temperature. Overestimation of the riser outlet temperature can be attributed to the insufficient heat losses. Therefore, a physically meaningful combination of the values of uncertain input parameters in the calibrated case is suggested as follows:

(i) The inlet water temperature had to be increased by $0.8^{\circ} \mathrm{C}$ in comparison to the measured value, so the calculated water temperature at the riser inlet matched the experimental value. A similar effect could be achieved by increasing the heater power. The adjustment of $+0.8^{\circ} \mathrm{C}$ for the inlet water temperature is within the range of the measurement uncertainty $\pm 1^{\circ} \mathrm{C}$.

(ii) The heat loss in the riser had to be $0.2 \mathrm{~kW}$, so the riser outlet water temperature matched the experimental 
TABLE 3: Test section response to the variation of the input parameters.

\begin{tabular}{|c|c|c|c|c|}
\hline \multirow{2}{*}{ Increased input parameter } & \multicolumn{4}{|c|}{ System response } \\
\hline & Riser inlet temperature & Riser outlet temperature & Riser void & Inlet pressure \\
\hline Inlet temperature & + & + & + & - \\
\hline Riser heat loss & 0 & - & - & + \\
\hline Heater power & + & + & + & - \\
\hline Inlet loss coefficient & 0 & 0 & 0 & + \\
\hline Outlet pressure & 0 & 0 & - & + \\
\hline
\end{tabular}

Increase: + , decrease: - , and no effect: 0 .

TABLE 4: Calibrated input parameters in the I-1, I-2 base cases.

\begin{tabular}{lc}
\hline Input parameter & Calibrated value \\
\hline Inlet temperature correction, Tin $\left({ }^{\circ} \mathrm{C}\right)$ & +0.8 \\
Heat loss in the riser, HL R $(\mathrm{kW})$ & 0.2 \\
Inlet loss coefficient, Kin $(-)$ & 28 \\
\hline
\end{tabular}

value. A similar value $(0.15 \mathrm{~kW} /$ channel $)$ was found in a later study in CIRCUS-IV with 4 active channels.

5.1.2. Full Loop Input Calibration. Further parametric study was performed for the uncertain input parameters of the whole loop model which were not addressed in the previous step: inlet valve loss coefficient, heat losses along the downcomer. From this step, the inlet valve loss coefficient of 28 was obtained.

From analysis at stage 1 , we found that the most influential uncertain parameters in the input are water temperature at the inlet and heat loss in the riser.

5.2. Stage 2: Code Validation against Natural Circulation TwoPhase Flow Instability. The validation of RELAP5 was carried out using data from I-1 and I-2 tests. The input calibrated against steady state test $\mathrm{S}-1$ was used as a base case input for I-1 and I-2 tests. Only water temperature at the inlet was changed to $93.6^{\circ} \mathrm{C}$ and $100.6^{\circ} \mathrm{C}$ for I-1 and I-2, respectively, which is $0.8^{\circ} \mathrm{C}$ higher than measured in the experiments (Table 4). First, detailed comparison between experimental data and code prediction with base case input was carried out. Second, variation of the uncertain input parameters was used in order to assess the ranges of variation in the system response. The following thermal-hydraulic parameters were used for comparison: maximum, minimum, and time-averaged values of the inlet flow rate, inlet pressure, water temperatures at the riser inlet, middle, and outlet, and the oscillation period.

In Figures 8-12 we present a comparison between system parameters predicted with the base case input and experimental data from I-1 test. In the I-1 test, the oscillation period was overestimated by $27 \%$; the average and maximum inlet flow rate agreed with the experiment (Figure 8 , Table 5). The minimum inlet flow rate was overestimated by $32 \%$. This is in the range of experimental uncertainty due to the fact that the minimum inlet flow rate during incubation period was small and oscillating in the range of $\pm 30 \%$. The minimum inlet pressure was 29 mbar higher than the experimental value (Figure 9, Table 5) during flashing, possibly due to the underestimation of void fraction in the test section.
The values of riser inlet, middle, and outlet water temperature were underestimated up to $1.2^{\circ} \mathrm{C}$ (Figures 10-12, Table 5). A possible reason for the discrepancies in prediction of the inlet pressure and riser water temperatures is too large heat loss in the riser $(0.2 \mathrm{~kW})$, which was calibrated using S-1 test data.

In Figures 13-17 we present a comparison between system parameters predicted with the base case input and experimental data from I-2 test with higher amplitude and higher frequency oscillation in comparison to I-1 test. The oscillation period and inlet pressure agreed with the experiment (Figures 13 and 14, Table 6). The maximum inlet flow rate was overestimated by $16 \%$, while the averaged amplitude was correctly predicted (Figure 13, Table 6). Riser water temperature was underestimated from $0.1^{\circ} \mathrm{C}$ to $1.6^{\circ} \mathrm{C}$ (Figures 15,16 , and 17 , Table 6). The outlet riser water temperature was significantly underestimated. Similar to I-1, it is possible that the heat loss was smaller in test I-2 than in S-1.

Parametric studies were performed for tests I- 1 and I-2 in order to assess the effect of the uncertain input parameters on system behavior. The influential parameters were varied from the base case values within their possible ranges, that is, inlet water temperature $\pm 1^{\circ} \mathrm{C}$, riser heat loss $\pm 0.2 \mathrm{~kW}$, and inlet valve loss coefficient $\pm 25 \%$. Other parameters such as heat loss in the downcomer were not varied since their influence has been shown to be negligible at the input calibration stage. Tables 5 and 6 show comparison between measured values and possible variation of predicted parameters for tests I-1 and I-2. The differences in oscillation period and inlet flow rate are normalized to the experimental values; the differences in riser water temperature and inlet pressure are absolute values.

The analysis of I-1 showed that the results are very sensitive to variations in riser heat loss and inlet water temperature (Table 5). Decreasing heat loss in the riser or increasing water temperature at the inlet created oscillations with higher frequency and amplitude. The higher frequency is due to the fact that time required for water in the riser to reach saturation temperature becomes shorter. The higher amplitude is caused by increase in amount of void generated in the riser during the flashing period and higher buoyancy effects due to higher water temperature. Increasing the heat loss in the riser or decreasing water temperature at the inlet had opposite effects on the system behavior. Variations in the inlet loss coefficient did not significantly affect the results.

The oscillation period was overestimated by the code for test I-1 in most cases (Table 5). The average and maximum 
TABLE 5: Difference between calculated and experimental values, test I-1.

\begin{tabular}{|c|c|c|c|c|c|c|c|c|}
\hline \multirow{2}{*}{\multicolumn{2}{|c|}{ Parameters }} & \multirow{3}{*}{ Calib. input } & \multirow{2}{*}{\multicolumn{6}{|c|}{ Varied input parameters }} \\
\hline & & & & & & & & \\
\hline & & & $\begin{array}{l}\text { Tin } \\
-1^{\circ} \mathrm{C}\end{array}$ & $\begin{array}{l}\text { Tin } \\
+1^{\circ} \mathrm{C}\end{array}$ & $\begin{array}{l}\text { HL R } \\
0 \mathrm{~kW}\end{array}$ & $\begin{array}{c}\text { HL R } \\
0.4 \mathrm{~kW}\end{array}$ & $\begin{array}{l}\text { Kin } \\
-25 \%\end{array}$ & $\begin{array}{c}\text { Kin } \\
+25 \%\end{array}$ \\
\hline \multicolumn{2}{|c|}{ Oscillation period (\%) } & 27.13 & 39.75 & 9.21 & -3.84 & 50.76 & 27.74 & 25.30 \\
\hline \multirow{3}{*}{ Flow rate $(\%)$} & Average & 7.07 & -1.16 & 10.03 & 3.27 & -2.07 & 7.73 & 5.04 \\
\hline & Maximum & -4.27 & -16.91 & 14.62 & 28.78 & -40.38 & -4.47 & -0.09 \\
\hline & Minimum & 31.65 & 28.41 & 47.90 & 30.72 & 35.73 & 32.57 & 31.67 \\
\hline \multirow{3}{*}{ Inlet riser temperature $\left({ }^{\circ} \mathrm{C}\right)$} & Average & -1.23 & -1.40 & -0.75 & -1.00 & -0.82 & -1.29 & -1.15 \\
\hline & Maximum & -1.00 & -1.01 & -0.94 & -0.87 & -0.98 & -1.07 & -0.95 \\
\hline & Minimum & -0.37 & -0.96 & 0.13 & -0.95 & 0.91 & -0.44 & -0.46 \\
\hline \multirow{3}{*}{ Middle tiser temperature $\left({ }^{\circ} \mathrm{C}\right)$} & Average & -0.23 & -0.55 & 0.27 & -0.30 & 0.24 & -0.31 & -0.21 \\
\hline & Maximum & 0.05 & 0.00 & 0.18 & 0.38 & -0.24 & 0.02 & 0.07 \\
\hline & Minimum & -0.38 & -0.99 & 0.17 & -0.24 & 0.29 & -0.49 & -0.41 \\
\hline \multirow{3}{*}{ Outlet riser temperature $\left({ }^{\circ} \mathrm{C}\right)$} & Average & -1.21 & -1.61 & -0.56 & -0.62 & -0.98 & -1.30 & -1.17 \\
\hline & Maximum & 0.31 & 0.35 & 0.29 & 0.22 & 0.29 & 0.30 & 0.28 \\
\hline & Minimum & -1.21 & -1.85 & -0.59 & -0.48 & -1.25 & -1.33 & -1.21 \\
\hline \multirow{3}{*}{ Inlet pressure (mbar) } & Average & 2.52 & 3.77 & 2.74 & 2.47 & 4.06 & 2.60 & 1.45 \\
\hline & Maximum & 3.53 & 3.92 & 7.88 & 6.14 & 3.76 & 6.23 & 4.58 \\
\hline & Minimum & 29.07 & 37.11 & 13.71 & 0.69 & 49.49 & 33.78 & 18.78 \\
\hline
\end{tabular}

The values in bold are maximum and minimum values obtained in simulations.

TABLE 6: Difference between calculated and experimental values, test I-2.

\begin{tabular}{|c|c|c|c|c|c|c|c|c|}
\hline \multirow[t]{2}{*}{ Parameters } & & \multirow{2}{*}{ Calib. input } & \multicolumn{6}{|c|}{ Varied input parameters } \\
\hline & & & $\begin{array}{l}\text { Tin } \\
-1^{\circ} \mathrm{C}\end{array}$ & $\begin{array}{l}\text { Tin } \\
+1^{\circ} \mathrm{C}\end{array}$ & $\begin{array}{l}\text { HL R } \\
0 \mathrm{~kW}\end{array}$ & $\begin{array}{c}\text { HL R } \\
0.4 \mathrm{~kW}\end{array}$ & $\begin{array}{c}\text { Kin } \\
-25 \%\end{array}$ & $\begin{array}{c}\text { Kin } \\
+25 \%\end{array}$ \\
\hline \multicolumn{2}{|l|}{ Oscillation period (\%) } & $-0.46 \%$ & $-5.59 \%$ & $-\mathbf{1 7 . 0 0} \%$ & $-3.82 \%$ & $-8.40 \%$ & $2.07 \%$ & $-4.95 \%$ \\
\hline \multirow{3}{*}{ Flow rate (\%) } & Average & $0.21 \%$ & $-4.76 \%$ & $5.88 \%$ & $-0.58 \%$ & $-1.73 \%$ & $1.94 \%$ & $-3.11 \%$ \\
\hline & Maximum & $16.58 \%$ & $24.70 \%$ & $34.25 \%$ & $23.42 \%$ & $27.39 \%$ & $20.18 \%$ & $18.03 \%$ \\
\hline & Minimum & $26.38 \%$ & $-4.04 \%$ & $13.96 \%$ & $16.60 \%$ & $7.59 \%$ & $27.26 \%$ & $8.95 \%$ \\
\hline \multirow{3}{*}{ Inlet riser temperature $\left({ }^{\circ} \mathrm{C}\right)$} & Average & -0.41 & -0.66 & -0.11 & -0.44 & -0.55 & -0.42 & -0.43 \\
\hline & Maximum & -1.29 & -1.50 & -1.20 & -1.25 & -1.46 & -1.29 & -1.27 \\
\hline & Minimum & -0.62 & -1.02 & -0.11 & -0.70 & -0.77 & -0.64 & -0.62 \\
\hline \multirow{3}{*}{ Middle riser temperature $\left({ }^{\circ} \mathrm{C}\right)$} & Average & -0.14 & -0.51 & -0.75 & -0.24 & -0.53 & -0.19 & -0.11 \\
\hline & Maximum & -1.26 & -1.35 & -0.80 & -1.17 & -1.27 & -1.16 & -1.27 \\
\hline & Minimum & 0.47 & 0.13 & -0.44 & 0.64 & 0.22 & 0.43 & 0.53 \\
\hline \multirow{3}{*}{ Outlet riser temperature $\left({ }^{\circ} \mathrm{C}\right)$} & Average & -1.18 & -2.14 & -2.47 & -1.53 & -2.63 & -1.12 & -1.59 \\
\hline & Maximum & -1.46 & -1.56 & -1.04 & -1.20 & -1.55 & -1.51 & -1.33 \\
\hline & Minimum & -1.64 & -3.06 & -2.40 & -1.95 & -3.35 & -1.70 & -1.93 \\
\hline \multirow{3}{*}{ Inlet pressure (mbar) } & Average & 5.94 & -3.60 & 2.61 & 5.63 & -4.74 & 9.00 & 3.72 \\
\hline & Maximum & 4.59 & -2.78 & 1.00 & 8.44 & -0.46 & 16.21 & 7.31 \\
\hline & Minimum & 12.37 & -4.10 & -10.52 & 3.47 & -8.11 & 21.66 & -2.71 \\
\hline
\end{tabular}

The values in bold are maximum and minimum values obtained in simulations.

inlet flow rate agreed with the experimental values. The minimum inlet flow rate was overestimated by $30 \div 40 \%$, which is in the range of experimental uncertainty. In most of the calculations, the minimum inlet pressure was overestimated and the riser water temperature was underestimated.

Results of the I-2 test simulations show that the solution is less sensitive to the variations in the uncertain input parameters (Table 6).
Simulation and experimental data are summarized and compared in Table 7 . The ranges of uncertainty in experimental data were obtained by comparing the average value of the parameter with the maximum and minimum values for a number of oscillations, not taking into account measurement uncertainties $\left( \pm 1^{\circ} \mathrm{C}, \pm 30 \mathrm{mbar}, \pm 0.0002 \mathrm{l} / \mathrm{s}\right)$. The ranges of predicted parameters in Table 7 were obtained by comparing the results from the calibrated inputs and the 
TABLE 7: Calculated and experimental values with uncertainties.

\begin{tabular}{|c|c|c|c|c|c|c|c|c|c|c|c|}
\hline \multicolumn{2}{|c|}{ Parameters } & \multicolumn{5}{|c|}{$\mathrm{I}-1$} & \multicolumn{5}{|c|}{$\mathrm{I}-2$} \\
\hline & & \multirow[t]{2}{*}{ Exp. } & \multirow{2}{*}{$\begin{array}{l}\text { Calib. } \\
\text { input }\end{array}$} & \multicolumn{3}{|c|}{ Uncertainty } & \multirow[t]{2}{*}{ Exp. } & \multirow{2}{*}{$\begin{array}{l}\text { Calib. } \\
\text { input }\end{array}$} & \multicolumn{3}{|c|}{ Uncertainty } \\
\hline & & & & $\begin{array}{l}\text { Exp. } \\
\text { Unc. }\end{array}$ & $\begin{array}{c}\text { Calc. } \\
\text { Unc. } \\
(+)\end{array}$ & $\begin{array}{c}\text { Calc. } \\
\text { Unc. } \\
(-)\end{array}$ & & & $\begin{array}{l}\text { Exp. } \\
\text { Unc. }\end{array}$ & $\begin{array}{c}\text { Calc. } \\
\text { Unc. } \\
(+)\end{array}$ & $\begin{array}{c}\text { Calc. } \\
\text { Unc. } \\
(-)\end{array}$ \\
\hline Oscillation & eriod (s) & 49.1 & 62.4 & \pm 0.1 & 11.6 & 15.2 & 14.3 & 14.2 & \pm 0.1 & 0.4 & 2.4 \\
\hline \multirow{3}{*}{$\begin{array}{l}\text { Flow rate } \\
(\mathrm{L} / \mathrm{s})\end{array}$} & Average & 0.058 & 0.062 & \pm 0.01 & 0.002 & 0.005 & 0.126 & 0.126 & \pm 0.07 & 0.007 & 0.006 \\
\hline & Maximum & 0.235 & 0.225 & -0.015 & 0.078 & 0.085 & 0.282 & 0.329 & -0.007 & 0.050 & 0.000 \\
\hline & Minimum & 0.024 & 0.031 & +0.017 & 0.004 & 0.001 & 0.029 & 0.036 & +0.009 & 0.000 & 0.009 \\
\hline \multirow{3}{*}{$\begin{array}{l}\text { Inlet riser } \\
\text { temp. }\left({ }^{\circ} \mathrm{C}\right)\end{array}$} & Average & 105.6 & 104.4 & \pm 0.1 & 0.5 & 0.2 & 106.0 & 105.6 & 0.0 & 0.308 & 0.246 \\
\hline & Maximum & 109.0 & 108.0 & -0.4 & 0.1 & 0.1 & 110.2 & 108.9 & -1.0 & 0.089 & 0.209 \\
\hline & Minimum & 98.1 & 97.7 & -0.1 & 1.3 & 0.6 & 103.9 & 103.3 & +0.1 & 0.515 & 0.401 \\
\hline \multirow{3}{*}{$\begin{array}{l}\text { Middle riser } \\
\text { temp. }\left({ }^{\circ} \mathrm{C}\right)\end{array}$} & Average & 102.2 & 102.0 & \pm 0.1 & 0.5 & 0.3 & 104.3 & 104.2 & 0.0 & 0.023 & 0.617 \\
\hline & Maximum & 106.4 & 106.4 & -0.1 & 0.3 & 0.3 & 107.3 & 106.0 & -0.3 & 0.453 & 0.096 \\
\hline & Minimum & 98.8 & 98.4 & +0.1 & 0.7 & 0.6 & 102.9 & 103.4 & +0.1 & 0.165 & 0.911 \\
\hline \multirow{3}{*}{$\begin{array}{l}\text { Outlet riser } \\
\text { temp. }\left({ }^{\circ} \mathrm{C}\right)\end{array}$} & Average & 102.0 & 100.8 & 0.0 & 0.7 & 0.4 & 103.8 & 102.6 & -0.2 & 0.054 & 1.454 \\
\hline & Maximum & 104.5 & 104.8 & -0.3 & 0.0 & 0.1 & 105.2 & 103.8 & -0.3 & 0.421 & 0.094 \\
\hline & Minimum & 99.9 & 98.6 & -0.1 & 0.7 & 0.6 & 102.7 & 101.1 & +0.2 & 0.000 & 1.704 \\
\hline \multirow{3}{*}{$\begin{array}{l}\text { Inlet pressure } \\
\text { (bar) }\end{array}$} & Average & 1.651 & 1.653 & 0.000 & 0.002 & 0.001 & 1.642 & 1.648 & 0.000 & 0.003 & 0.011 \\
\hline & Maximum & 1.653 & 1.657 & \pm 0.013 & 0.004 & 0.000 & 1.660 & 1.665 & \pm 0.020 & 0.012 & 0.007 \\
\hline & Minimum & 1.595 & 1.624 & \pm 0.002 & 0.020 & 0.028 & 1.584 & 1.596 & \pm 0.004 & 0.009 & 0.023 \\
\hline
\end{tabular}

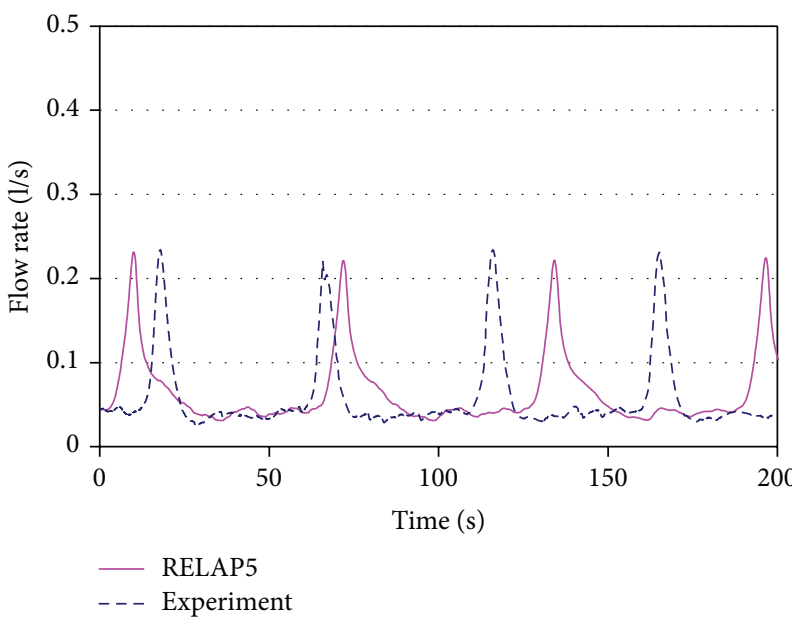

Figure 8: Inlet flow rate, test I-1.

maximum, minimum values obtained by variation of the uncertain input parameters within their possible ranges (in Tables 5 and 6).

In Figures 18-23 we show experimental data and calculation results for tests I-1 and I-2 (see also Table 7). For most of the considered parameters the ranges of experimental and simulation uncertainty overlap with each other. Only for the high frequency oscillation test I-2, the code consistently overestimated the maximum inlet flow rate by at least $16 \%$ (Figure 18). A possible reason for this discrepancy might be the use of the steady state two-phase flow regime maps

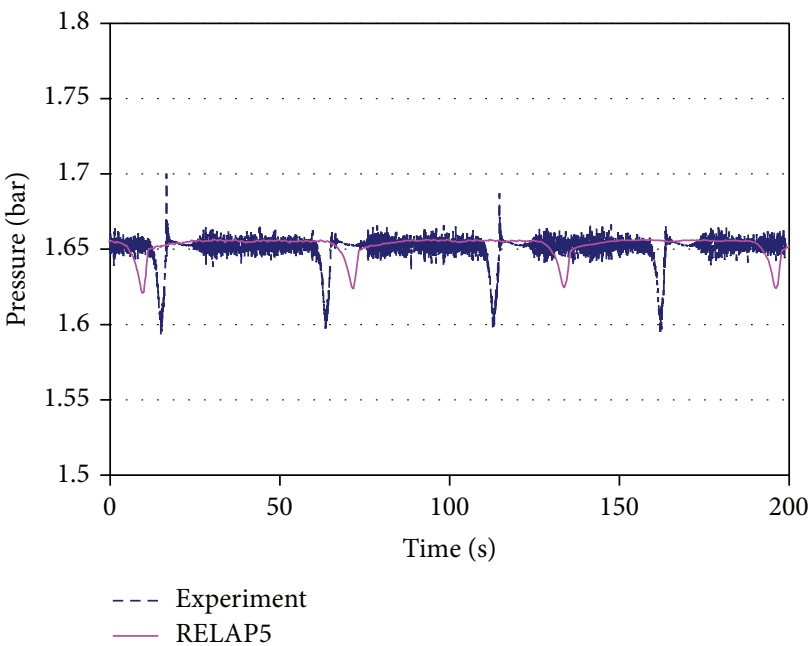

Figure 9: Inlet pressure, test I-1.

in RELAP5 for calculation of rapidly changing oscillatory flows. An indirect confirmation for this hypothesis is the fact that the discrepancy was smaller in I-1 case where flow rate changes are slower. We noticed in the parametric study that quite often if one output parameter gets closer to the experimental value, some others would be more off. The uncertainty bars in the figures do not reflect this fact. Criteria which take into account simultaneously several output parameters are needed for better evaluation of the code validity. Such comparison is, however, out of the scope of this work. 


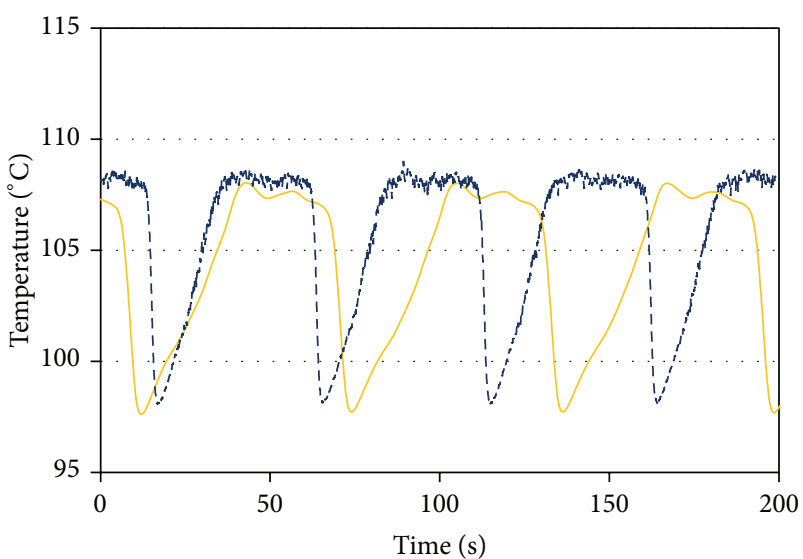

RELAP5

- - - Experiment

FIgURE 10: Inlet riser water temperature, test I-1.

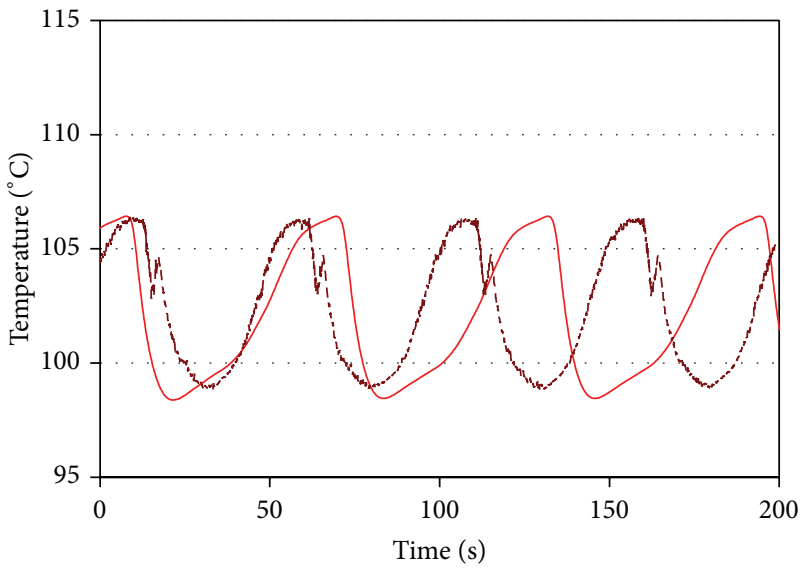

- RELAP5

- - Experiment

FIgURE 11: Middle riser water temperatures, test I-1.

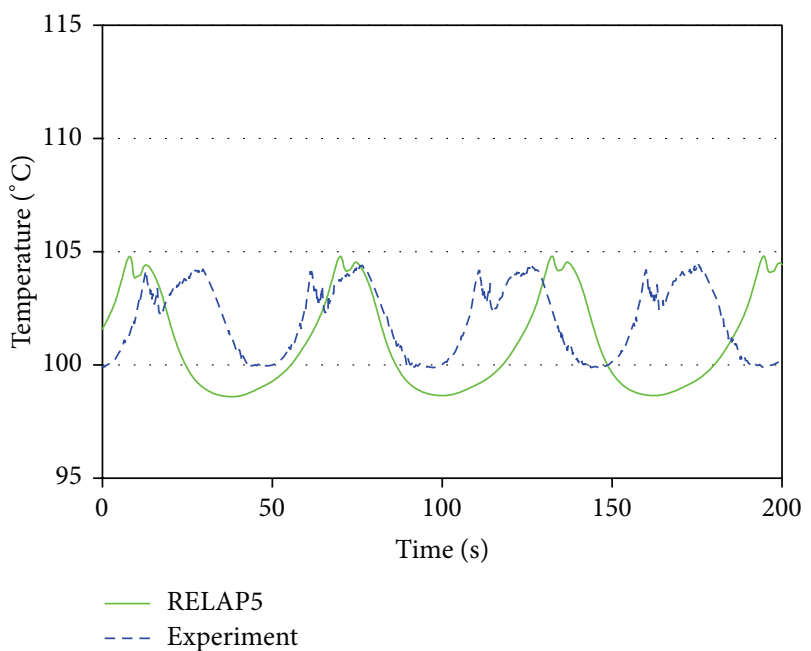

FIGURE 12: Outlet riser water temperatures, test I-1.

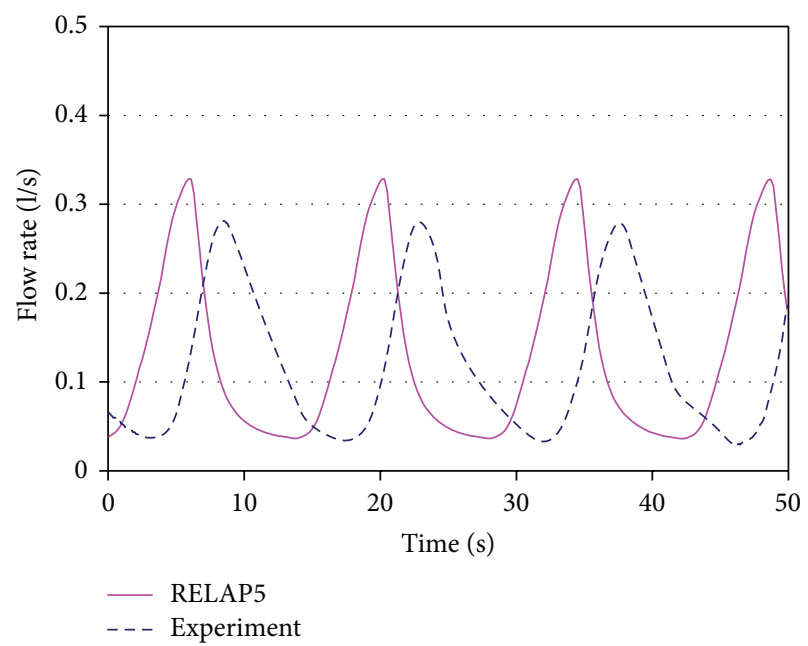

Figure 13: Inlet flow rate, test I-2.

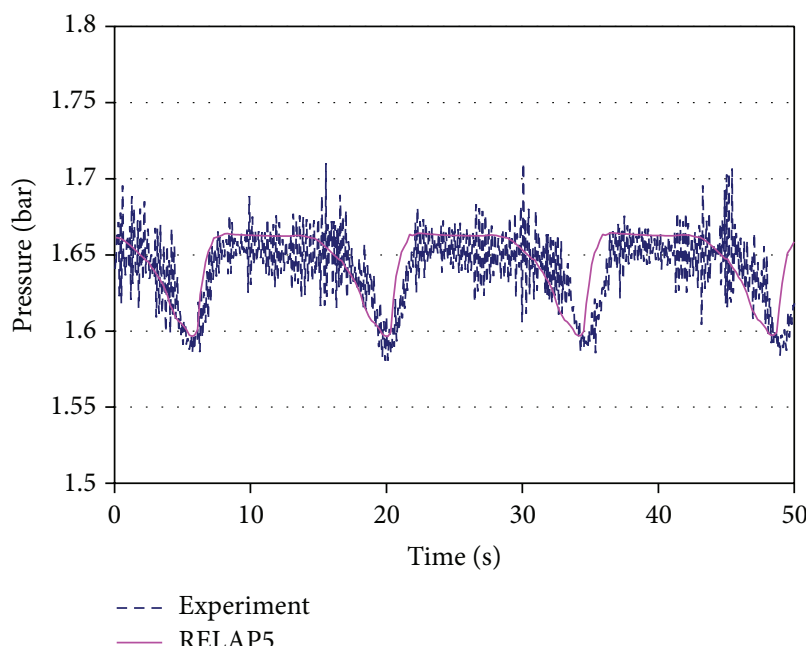

FIGURE 14: Inlet pressure, test I-2.

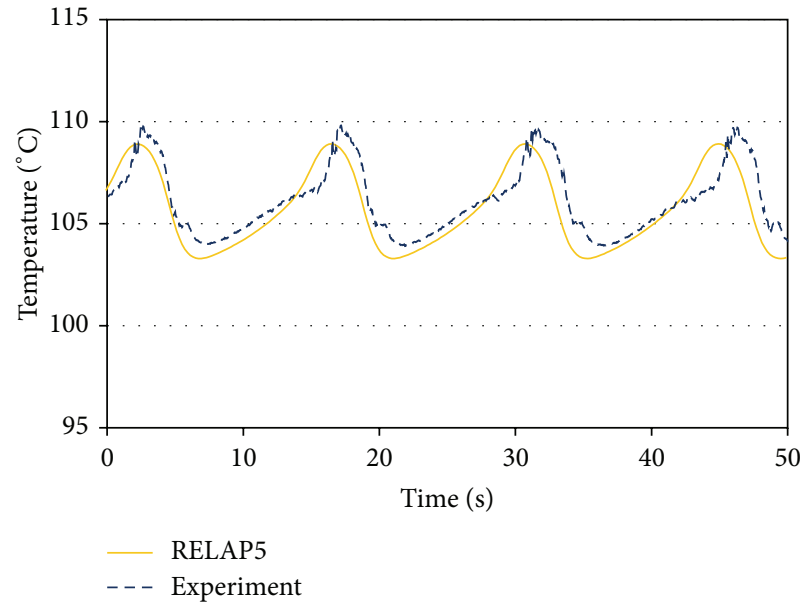

FIgURE 15: Inlet riser water temperatures, test I-2. 


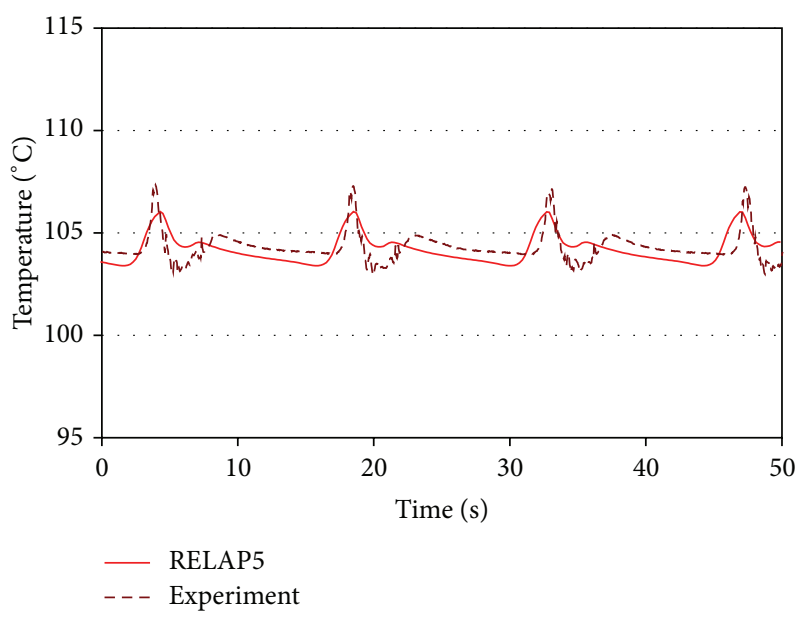

FIGURE 16: Middle riser water temperatures, test I-2.

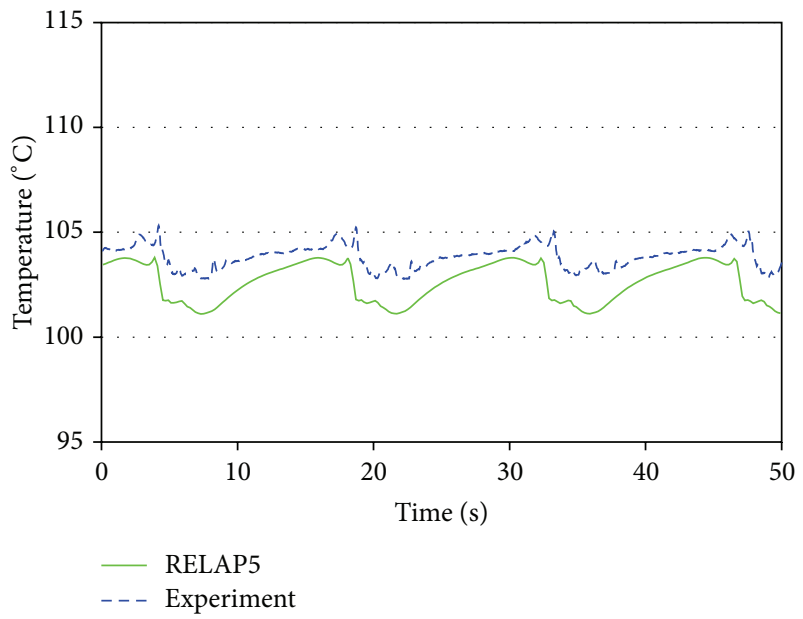

FIgURE 17: Outlet riser water temperatures, test I-2.

\section{Conclusions}

The RELAP5 code was validated against natural circulation two-phase flow instability at atmospheric pressure in CIRCUS-IV single channel tests. A procedure for the calibration of uncertain input parameters and validation of the code has been developed. The procedure employs (i) multiple measured parameters in different test regimes, (ii) separate consideration of the loop subsections with fixed inlet and outlet boundary conditions, and (iii) integral loop behavior.

In order to identify the most influential parameters and to reduce uncertainty in the code input we apply sensitivity study and knowledge about expected system response to separate variation of the parameters. Calibration of the input is carried out using single-phase steady state flow conditions.

Two tests with natural circulation oscillations were used for code validation: I-1 and I-2 with lower and higher frequency and amplitude, respectively. The results suggest that calculation and experimental uncertainties overlap, except for the I-2 test where the maximum inlet flow rate was overestimated. In the higher frequency instability regime,

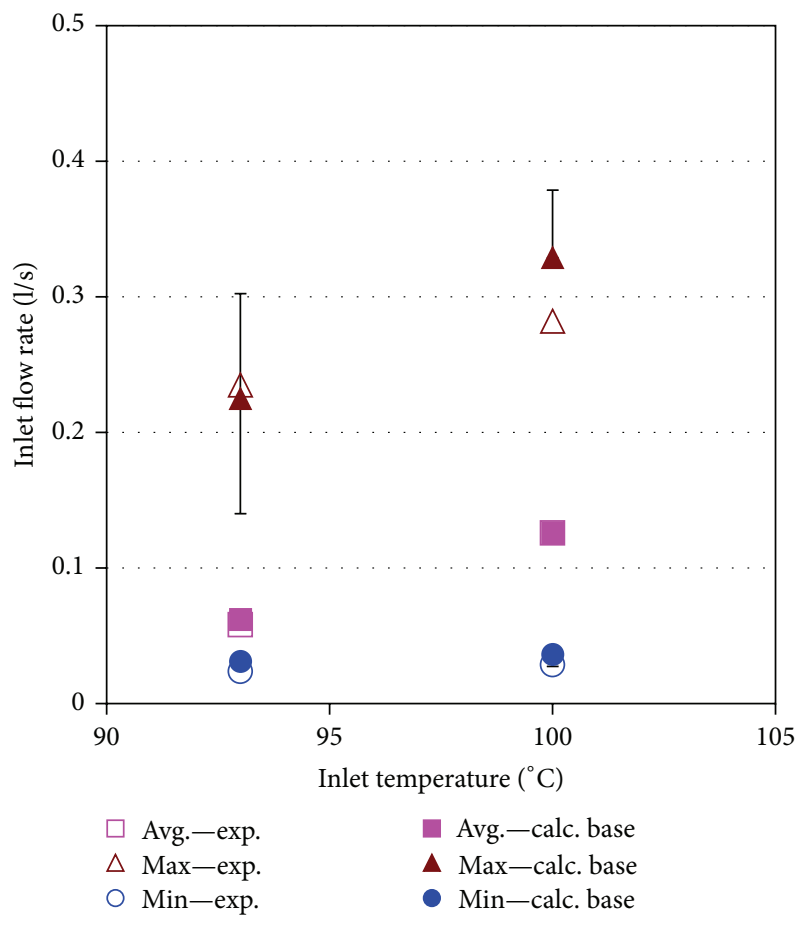

Figure 18: Inlet flow rate.

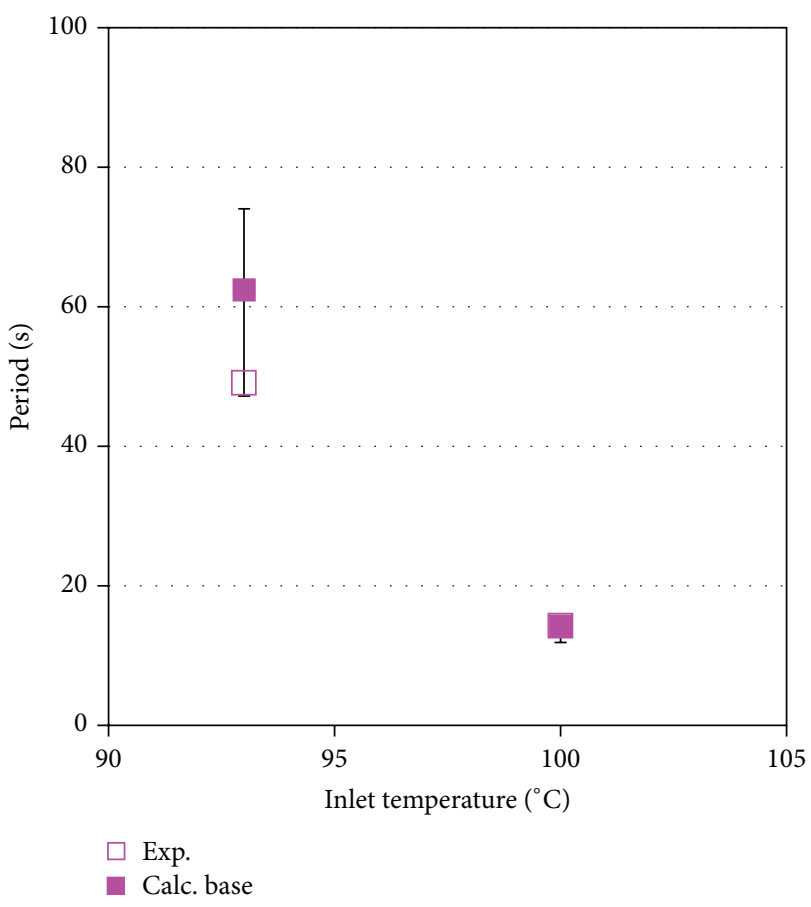

FIGURE 19: Oscillation period.

predicted system parameters are less sensitive to variations of the uncertain input parameters. One of the possible reasons for the discrepancy could be the steady state two-phase flow regime maps employed in the code. For further investigation of effect of the flow regime map on two-phase flow transients, 


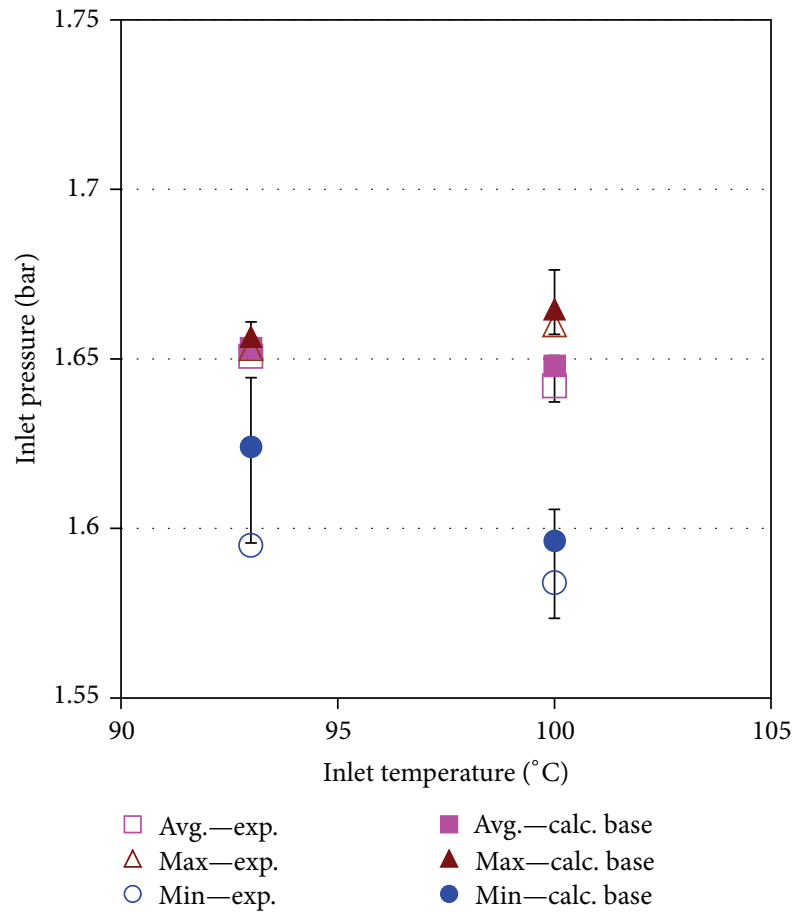

FIGURE 20: Inlet pressure.

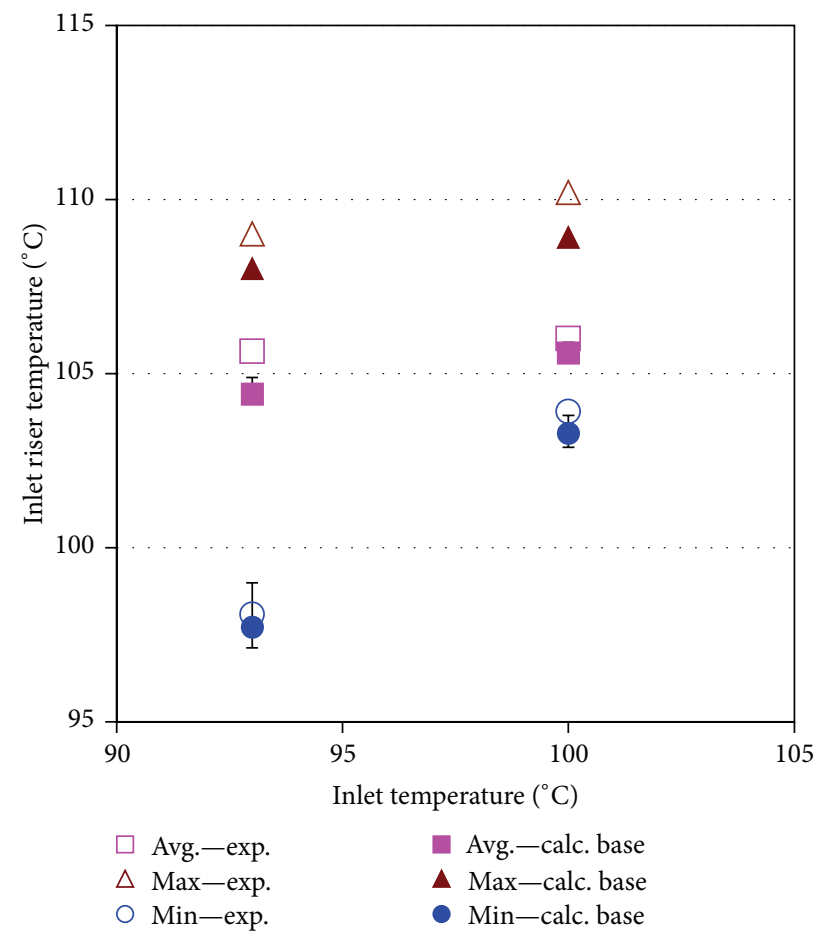

FIgURE 21: Inlet riser water temperature.

development of experiments for code validation would be necessary.

\section{Conflict of Interests}

The authors declare that there is no conflict of interests regarding the publication of this paper.

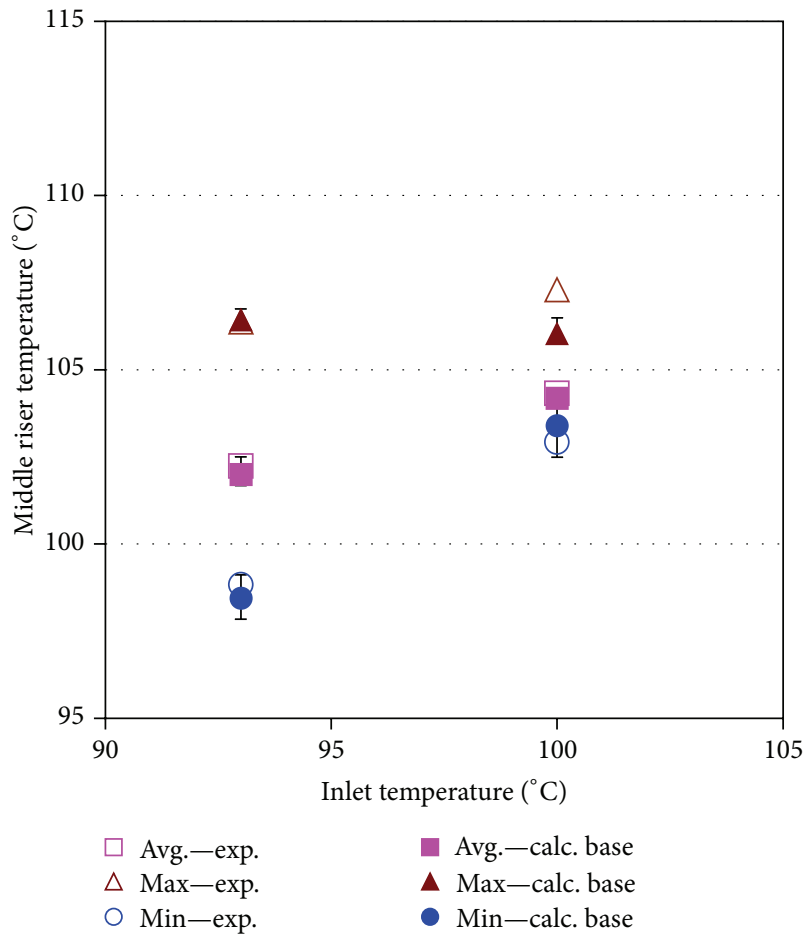

FIGURE 22: Middle riser water temperature.

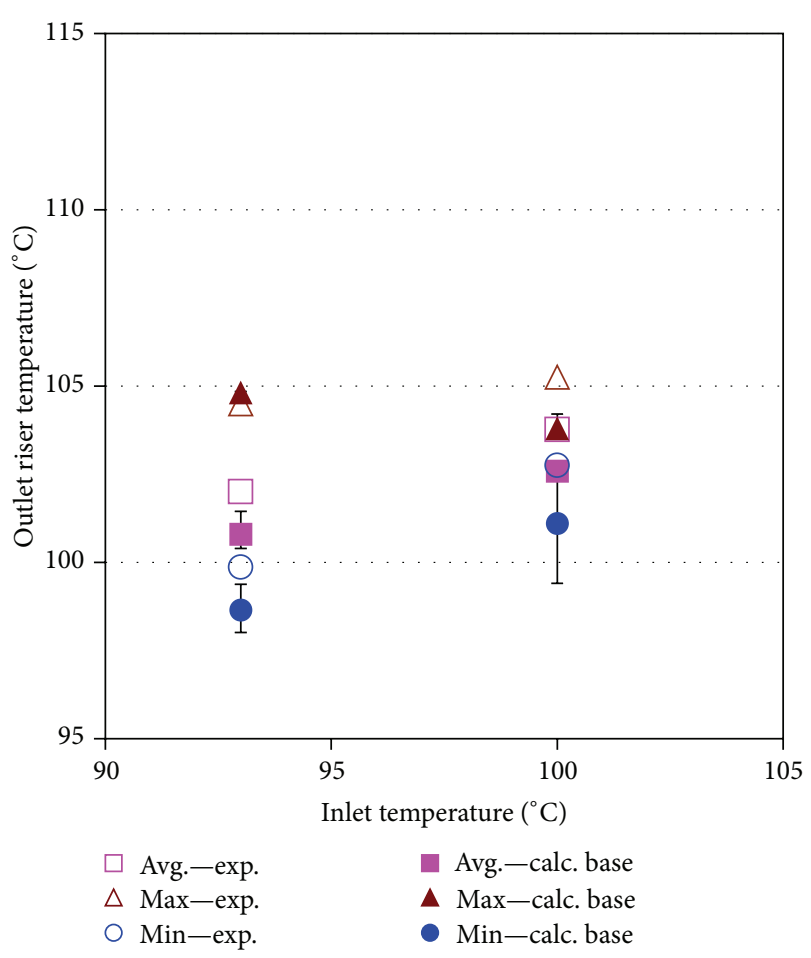

FIGURE 23: Outlet riser water temperature.

\section{Acknowledgments}

This work was supported partially by the Swedish Centre for Nuclear Technology (SKC). The authors would like to thank Professor Nam Dinh (North Carolina State University) for valuable discussions. They would like to thank Assistant 
Professor Tomasz Kozlowski (University of Illinois) for help with RELAP5. They are grateful to Mr. Dick de Haas and Mr. Coen Degen, MSc. (Delft University of Technology), for assistance with the experiments.

\section{References}

[1] V. H. Ransom, "RELAP5/MOD2: for PWR transient analysis," in Proceedings of the International Conference on Numerical Methods in Nuclear Engineering, Montreal, Canada, September 1983.

[2] D. Lucas, E. Krepper, and H.-M. Prasser, "Development of cocurrent air-water flow in a vertical pipe," International Journal of Multiphase Flow, vol. 31, no. 12, pp. 1304-1328, 2005.

[3] P. G. Prassinos and C. K. Liao, "Investigation of two-phase flow regimes in LOFT piping during loss-of-coolant experiments," Tech. Rep. NUREG/CR-0606, TREE-1244, EG\&G Idaho, 1979.

[4] J. D. Duncan, "SBWR, a simplified boiling water reactor," Nuclear Engineering and Design, vol. 109, no. 1-2, pp. 73-77, 1988.

[5] E. H. Wissler, H. S. Isbin, and N. R. Amundson, "Oscillatory behavior of a two-phase natural-circulation loop," AIChE Journal, vol. 2, no. 2, pp. 157-162, 1956.

[6] J. A. Boure, A. E. Bergles, and L. S. Tong, "Review of two-phase flow instability," Nuclear Engineering and Design, vol. 25, no. 2, pp. 165-192, 1973.

[7] M. Aritomi, J. H. Chiang, and M. Mori, "Geysering in parallel boiling channels," Nuclear Engineering and Design, vol. 141, no. 1-2, pp. 111-121, 1993.

[8] J. H. Chiang, M. Aritomi, and M. Mori, "Fundamental study on thermo-hydraulics during start-up in natural circulation boiling water reactors, (II) natural circulation oscillation induced by hydrostatic head fluctuation," Journal of Nuclear Science and Technology, vol. 30, no. 3, pp. 203-211, 1993.

[9] M. Furuya, F. Inada, and T. H. J. J. van der Hagen, "Flashinginduced density wave oscillations in a natural circulation BWR-mechanism of instability and stability map," Nuclear Engineering and Design, vol. 235, no. 15, pp. 1557-1569, 2005.

[10] M. Furuya, F. Inada, and T. H. J. J. van der Hagen, "Regional stability estimation of natural circulation BWRs using SIRIUS$\mathrm{N}$ facility," Journal of Nuclear Science and Technology, vol. 42, no. 4, pp. 341-350, 2005.

[11] W. J. M. de Kruijf, K. C. J. Ketelaar, G. Avakian et al., "Planned experimental studies on natural-circulation and stability performance of boiling water reactors in four experimental facilities and first results (NACUSP)," Nuclear Engineering and Design, vol. 221, no. 1-3, pp. 241-250, 2003.

[12] W. J. M. de Kruijf, T. Sengstag, D. W. de Haas, and T. H. J. J. van der Hagen, "Experimental thermohydraulic stability map of a Freon-12 boiling water reactor facility with high exit friction," Nuclear Engineering and Design, vol. 229, no. 1, pp. 75-80, 2004.

[13] R. Zboray, W. J. M. de Kruijf, T. H. J. J. van der Hagen, and R. Uddin, "Investigating the nonlinear dynamics of naturalcirculation, boiling two-phase flows," Nuclear Technology, vol. 146, no. 3, pp. 244-256, 2004.

[14] M. Ishii, S. Revankar, R. Dowlati et al., "Scientific design of Purdue University multidimensional integrated test assembly (PUMA) for GE SBWR," Tech. Rep. NUREG/CR-6309, US Nuclear Regulatory Commission, 1996.

[15] S. Kuran, Y. Xu, X. Sun et al., "Startup transient simulation for natural circulation boiling water reactors in PUMA facility,"
Nuclear Engineering and Design, vol. 236, no. 22, pp. 2365-2375, 2006.

[16] A. Manera and T. H. J. J. van der Hagen, "Stability of naturalcirculation-cooled boiling water reactors during startup: experimental results," Nuclear Technology, vol. 143, no. 1, pp. 77-88, 2003.

[17] C. P. Marcel, M. Rohde, and T. H. J. J. van der Hagen, "Out-ofphase flashing induced instabilities in the CIRCUS facility," in Proceedings of the 11th International Topical Meeting on Nuclear Reactor Thermal-Hydraulics (NURETH '05), Avignon, France, October 2005.

[18] M. Rohde, C. P. Marcel, A. Manera, T. H. J. J. van der Hagen, and B. Shiralkar, "Investigating the ESBWR stability with experimental and numerical tools: a comparative study," Nuclear Engineering and Design, vol. 240, no. 2, pp. 375-384, 2010.

[19] J. Paniagua, U. S. Rohatgi, and V. Prasad, "Modeling of thermal hydraulic instabilities in single heated channel loop during startup transients," Nuclear Engineering and Design, vol. 193, no. 1, pp. 207-226, 1999.

[20] F. Inada, M. Furuya, and A. Yasuo, "Thermo-hydraulic instability of boiling natural circulation loop induced by flashing (analytical consideration)," Nuclear Engineering and Design, vol. 200, no. 1, pp. 187-199, 2000.

[21] N. I. Kolev, "Validation of IVA computer code for flow boiling stability analysis," in Proceedings of the International Conference on Nuclear Engineering (ICONE '14), Miami, Fla, USA, July 2006.

[22] B. S. Shiralkar, M. Alamgir, and J. G. M. Andersen, "Thermalhydraulic aspects of the SBWR design," Nuclear Engineering and Design, vol. 144, no. 2, pp. 213-222, 1993.

[23] F. Schäfer and A. Manera, "Investigation of flashing-induced instabilities at the CIRCUS test facility using the code ATHLET," in Proceedings of the 29th International Meeting on Reactor Noise, Budapest, Hungary, May 2004.

[24] Y. Kozmenkov, U. Rohde, and A. Manera, "Validation of the RELAP5 code for the modeling of flashing-induced instabilities under natural-circulation conditions using experimental data from the CIRCUS test facility," Nuclear Engineering and Design, vol. 243, pp. 168-175, 2012.

[25] A. Petruzzi and F. D’Auria, "Approaches, relevant topics, and internal method for uncertainty evaluation in predictions of thermal-hydraulic system codes," Science and Technology of Nuclear Installations, vol. 2008, Article ID 325071, 17 pages, 2008.

[26] P. Kudinov, Numerical simulation of hydrodynamics and heat transfer in problems with convective instability and non-unique solution [Ph.D. thesis], Dnepropetrovsk National University, Dnepropetrovsk, Ukraine, 2000 (Russian).

[27] T. H. J. J. van der Hagen, A. J. C. Stekelenburg, and D. D. B. van Bragt, "Reactor experiments on type-I and type-II BWR stability”, Nuclear Engineering and Design, vol. 200, no. 1-2, pp. 177-185, 2000.

[28] V.-A. Phung, P. Kudinov, and M. Rohde, "Validation of RELAP5 with sensitivity analysis for uncertainty assessment for natural circulation two-phase flow instability," in Proceedings of the 13th International Topical Meeting on Nuclear Reactor Thermal Hydraulics (NURETH-13 '09), Paper 13P1248, Kanazawa, Japan, September-October 2009.

[29] USNRC and ISL, RELAP5/MOD3.3 Code Manual, Volume IV: Models and Correlations, USNRC \& ISL, Idaho Falls, Idaho, USA, 2001. 
[30] A. Manera, U. Rohde, H.-M. Prasser, and T. H. J. J. van der Hagen, "Modeling of flashing-induced instabilities in the startup phase of natural-circulation BWRs using the two-phase flow code FLOCAL," Nuclear Engineering and Design, vol. 235, no. 14, pp. 1517-1535, 2005.

[31] A. Petruzzi and F. D’Auria, "Thermal-hydraulic system codes in nulcear reactor safety and qualification procedures," Science and Technology of Nuclear Installations, vol. 2008, Article ID 460795, 16 pages, 2008. 


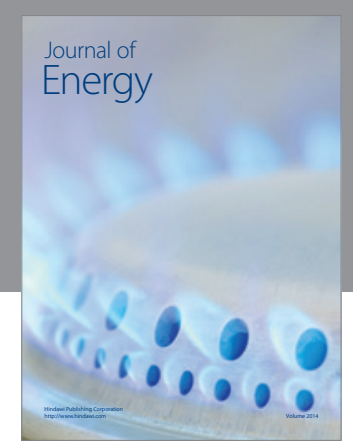

Journal of

Industrial Engineering
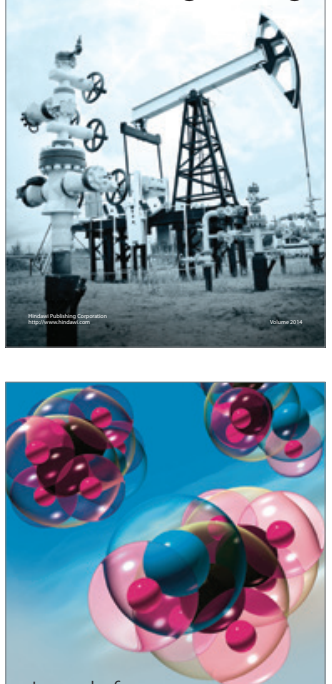

Fuels
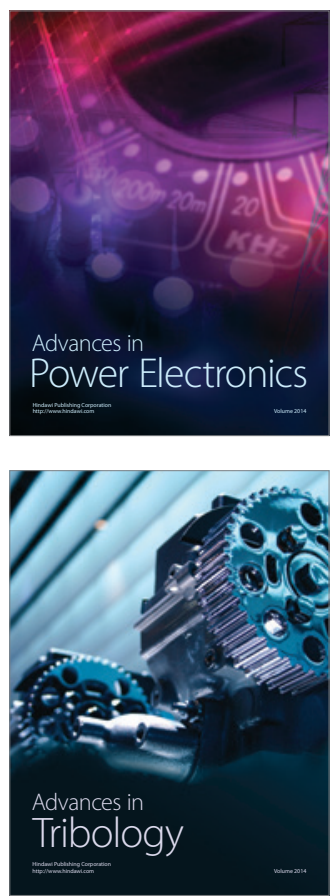

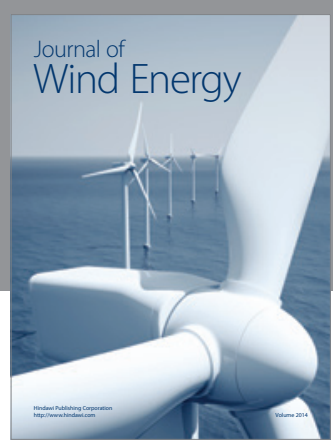

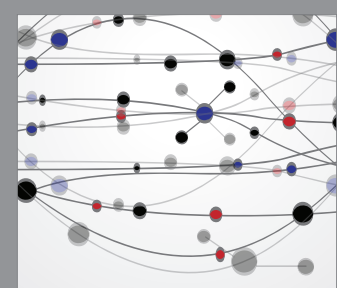

The Scientific World Journal

Submit your manuscripts at http://www.hindawi.com

Journal of

Structures
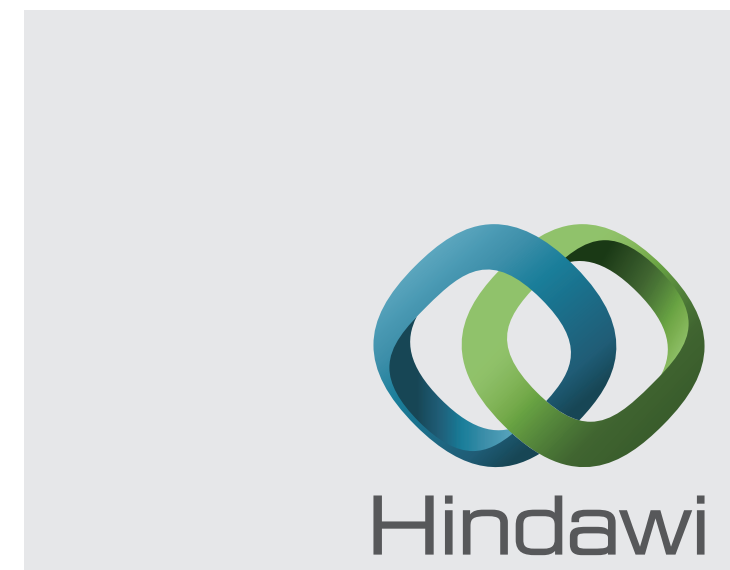

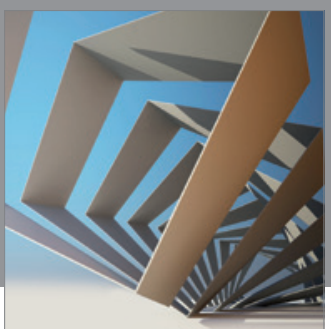

Rotating

Machinery
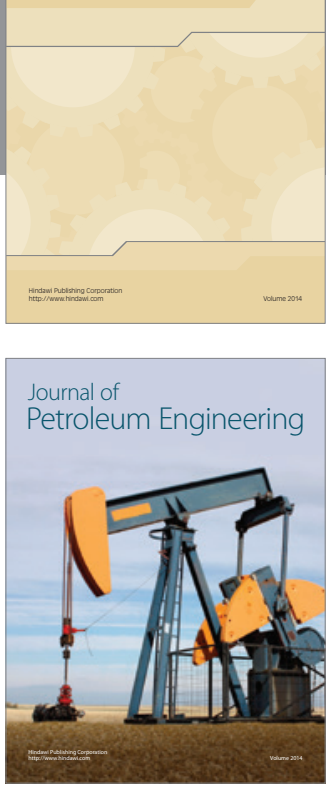

Journal of

Solar Energy
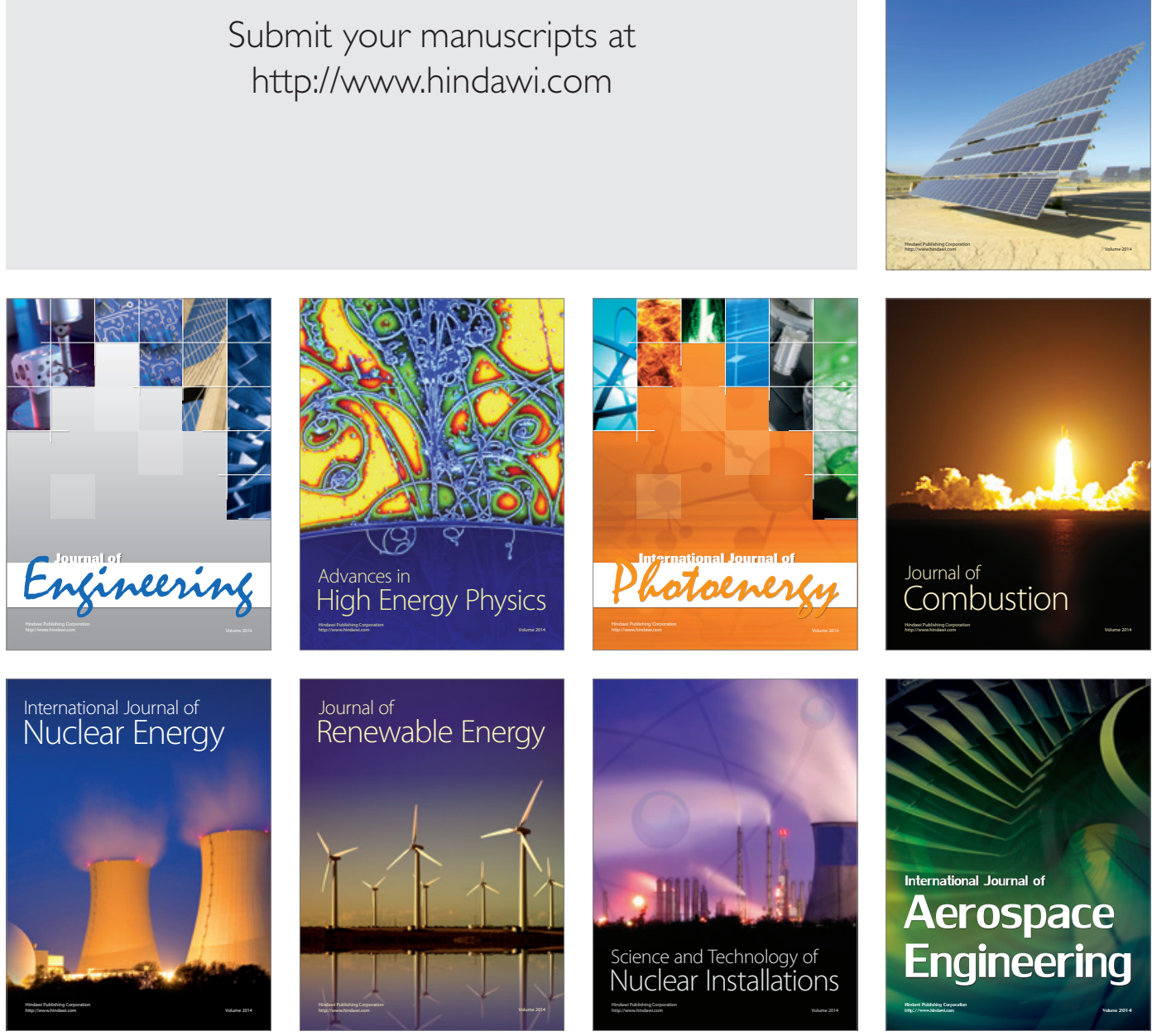